\title{
Missional metanoia: Missional spirituality in holistic theological education
}

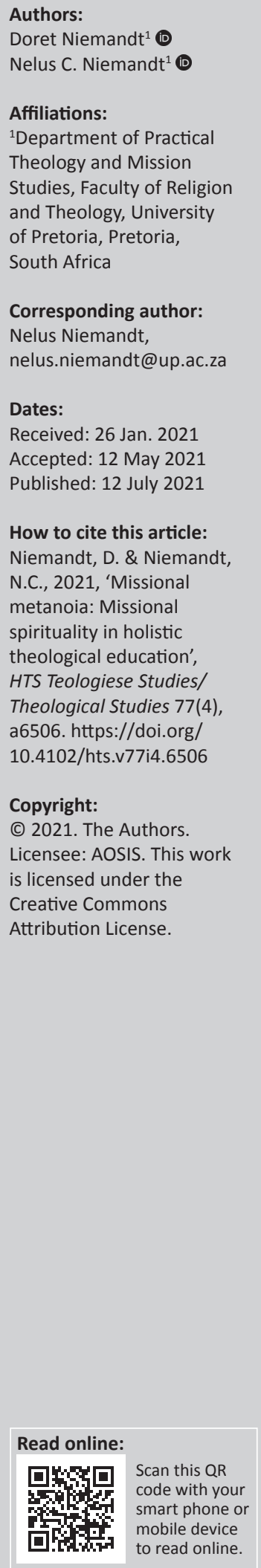

Theological education is in crisis having lost an important dimension with its main focus on quality academics often abstracted from real life. This study aimed to propose that the formation of spirituality is fundamental to theological education and that theological education should be a holistic formation. The setting of this study is re-imaging theological education in the Dutch Reformed Church (DRC), a denomination in the process of missional transformation, but it is also applicable to theological education in general. This study focused on the relation between theology and spirituality, the significance of missional spirituality in theological education and a probable model for the formation of a missional spirituality. The study found that theology and spirituality are interdependent, and theological education should thus focus on all the different areas of learning and formation, that is, minimum knowledge base, pass-on-able habits and skills, and attitudes and beliefs. Theological education should ultimately cultivate a missional spirituality, forming missional leaders for the church. Leaders who are equipped are able to equip others for God's mission. Theological education is not about obtaining a degree but in essence a process of formation and transformation. Wright asks: if the gospel is not transforming you, will it transform anything else? Transformation to be able to transform - a missional metanoia.

Contribution: This study provides a probable model for holistic theological education and the formation of a missional spirituality.

Keywords: theological education; missional transformation; Christian spirituality; missional spirituality; spiritual formation; missional leadership.

\section{Introduction}

Despite the inclination of theological education to focus on the intellectual, theological education is not responsible for and concerned with pure academics or the mere contestation of ideas. In a discussion with Moltmann on 30 June 2017 at the World Communion of Reformed Churches (WCRC) General Council, he noted that theology is not only for the so-called professionals and is not something you read, but it is something you do. Volf and Croasmun (2019:1) deemed that academic theology should be about what matters most: 'the true life in the presence of God'. When academic theology or theological education loses this dimension, theology becomes irrelevant (Volf \& Croasmun 2019):

The failure of theology to attend to its purpose is a loss for the church and for the world, for theology is uniquely qualified to explore what matters the most. And this is a loss for theology itself - for theology will either refocus itself on what matters the most or gradually cease to matter at all. (p. 1)

Theology and theological reflections are important because they are about what matters the most. And living the true life in the presence of God means theological education has to equip students, or rather everyone, for this life.

The backdrop of this research is the theological education of the Dutch Reformed Church (DRC). The DRC, in a process of missional transformation as described in their policy document, Framework Document on the Missional Nature and Calling of the DRC (DRC 2013), has already embarked on a journey to re-imagine theological education for the formation of missional leaders. However, this research is also applicable to theological education in general and proposes that the formation of a missional spirituality is fundamental to theological education.

Note: Special Collection: From timely exegesis to contemporary ecclesiology: Relevant hermeneutics and provocative embodiment of faith in a Corona-defined world - Festschrift for Stephan Joubert, sub-edited by Willem Oliver (University of South Africa). 
The research questions posed are as follows: What is the relation between theology and spirituality, what is the significance of missional spirituality in theological education and what is a probable model for the formation of a missional spirituality.

\section{Theology and spirituality}

The relation between theology and spirituality ${ }^{1}$ is clear. Theology and spirituality are irrevocably connected and interdependent. According to Schneiders (2002:135), theology attempts to grasp and articulate what is believed and lived, and it is the intellectual articulation of spirituality. Hernandez (2006:4) noted the indivisible relationship between theology and spirituality. Sheldrake (2010:62) asserted that the fundamental connection between theology and spirituality has become axiomatic. Van Niekerk (2019:28) stated that theology is ingrained in spirituality. However, this was not always the case as theology and spirituality have, separately, gone through various transitions. The most recent transitions can be mentioned here.

In recent decades, major shifts took place in the relationship between spirituality and theology. First, what was understood as 'spirituality' has changed considerably. 'It is no longer limited to monastic-clerical elites and has also broadened beyond attention to prayer and contemplation to include reflection on the values and lifestyle of all Christians' (Sheldrake 2010:61). Second, Christian spirituality is no longer concerned with defining 'perfection' in the abstract, rather it examines the complex mystery of human transformation in the context of a dynamic relationship with God (Sheldrake 2010:62). Spirituality is thus about all the different aspects concerning human life. According to Williams (1990:12), spiritualty is more than a science of interpreting exceptional private experiences and removing the distinction between the so-called compromising activities and spheres (the family, state, the individual body or psyche) and the so-called pure realities (the soul and the intelligible world), and spiritualty becomes more complex. He stated that spirituality 'must now touch on every area of human experience, the public and social, the painful, negative, even pathological byways of the mind, the moral and relational world' (Williams 1990:12). Spirituality is staying alive in Christ (Williams 2016:76). This change in the understanding of spirituality has a profound influence on the goal of spirituality. With this understanding, the Christian life is not about enlightenment, but wholeness (Williams 1990:12). Third, spiritualty is now connected with theology and biblical studies. This connection is partly because of the changes in theology. 'Theology has moved from a deductive, transcultural approach to reflection on the experience of God and the practices of discipleship in cultural particularity' (Sheldrake 2010:62). Waaijman (2006:2) also noted these two approaches when describing spirituality - the deductive approach, theologically orientated, and the inductive approach, starting from lived experience. The latter is no longer neglected. It can thus be concluded that theology and 1.In this article, spirituality refers to Christian spirituality. spirituality are interdependent. Hernandez (2006:131) stated that this interdependence means that knowing God implies loving God, 'theological impression gives way to spiritual expression in the same way that the reality of the expression itself solidifies the truth of the actual impression'. However, according to Schneiders, spirituality also goes beyond theology. Considering that both theology and spirituality have gone through shifts and changes, Schneiders (1986:273) stated that spirituality was secondary to theology, but 'spirituality has emerged as an autonomous dialogue partner demanding independence for the sake of mature interdependence'. Kourie (2009:148) also stated that spirituality, once regarded as a 'Cinderella' discipline, has returned to its rightful place and is wielding influence inside and outside of the academy.

Despite these ambiguities, specialists in spirituality concur that theology and spirituality are essential companions. They are united in their persistence that firstly, human experience is a genuine source of wisdom and knowledge about God; secondly, this human experience requires a form of interpretation obtained from a diverse and wide range of academic methods; and thirdly, the appropriate study of spirituality requires us to go beyond a sense of truth as neutral and objective (Endean 2005). These considerations demonstrate that spiritualty without theological reflection and theology not grounded in real life experience is not only inadequate but also feeble. Spirituality has liberated theology, and together, it has transformative potential (Kourie 2009:167). Spirituality exempts theology from the constraints of mere academics.

From this brief overview of theology and spirituality, it is clear that spirituality is more than an inward movement of contemplation and meditation, it is an outward movement concerning all aspects of life and it is about life itself. This means that spirituality is not about enlightenment, but about becoming whole and living a flourishing life. A flourishing life is not about wealth or success, but rather 'the good to which humans are meant to strive' (Volf \& Croasmun 2019:13). It has also become clear that theology is not detached from existence or experiences, and theology frames and points out the meaning of life. Becoming whole and living a flourishing life in God's presence is God's main concern for his creation and 'the purpose of theology is to discern, articulate, and commend visions of flourishing life in light of God's selfrevelation in Jesus Christ' (Volf \& Croasmun 2019:11).

True spirituality is a live, continuous personal relationship with the Creator God that fulfils my deepest human longings for inward and outward peace and gives me meaning and purpose for everyday life. Spirituality is of no use if it is not of earthly use. True spirituality is discovered in human relationships, built on the foundation of a relationship with God. (Amalraj 2009:9)

With this overview of theology and spirituality, the first research question is answered, and the establishment of this relation and interdependence between theology and spirituality leads to the next research question, namely the significance of missional spirituality in theological education. 


\section{Theological education and the formation of missional spirituality}

Theological education and spiritual formation are interdependent. Missional spirituality is a spirituality that plays an important role in re-establishing an important dimension that was lost. 'Missional' has become a supporting word, scaffolding, and missional spirituality can be understood as pointing towards authentic Christian spirituality.

Missional spirituality is a spirituality that ignites and nurtures a way of life for the sake of others. This brings us to the second research question: what is the significance of missional spirituality in theological education, especially with regard to the DRC's process of missional transformation.

Helland and Hjalmarson (2011:loc. 508-509) asserted that theological education is inherently spiritual as it addresses the whole person and inherently missional as it concerns God's mission to the world. This suggests that theological education is already forming spirituality, but when it is not performed intentionally and when theology ceases to focus on God's mission to the world, it is most likely an immature or reserved spirituality. It has lost an important dimension. Unfortunately, it seems that theological education lacks intentional spiritual formation. Naidoo (2010:189) asserted that theological education is in crisis - theological institutions are not equipping the right type of leaders or the purpose of theology is misunderstood, 'the theological curriculum is in disarray with minimal integration among the disciplines and a tendency to functionalism'. Johnson and Dreitcer (2001:vii-viii) observed that many congregational leaders have had no intentional training in spiritual formation and the consequence being the lack of mature spiritualities. The lack of intentional spiritual formation produces 'professionals'. There should be a fundamental shift in paradigms and practices 'from equipping managers to equipping spiritual directors and leaders, from maintenance to mission, from church at the centre to a kingdom frame' (Helland \& Hjalmarson 2011:loc. 223-2235).

Guder (ed. 1998:217) advocated that the model of academic learning, regarded as an 'abstract enterprise and based on observation rather than personal involvement', should be reconsidered and 'structured intentional formation needs to be rediscovered'. It is not enough to add another course or module for spiritual formation, and theological education as a whole needs to be re-evaluated - the content, but especially the methodology. Cannell indicated that when theological schools are confronted with the lack of spiritual growth, their response seems to be the addition of another course (Brynjolfson 2010:197), or as Helland and Hjalmarson (2011:loc. 2243) noted, to simply attempt to improve what has always been performed. Banks already wrote about reenvisioning theological education and alternative missional models 20 years ago. He noted that when certain questions regarding theological education come up, they are usually addressed as operational matters, concerning academics and administration, and not as theological matters (Banks 1999:9). Theological education is in desperate need of deep change.

Attending to the theological education crisis and addressing the adaptive challenge requires clarity on the primary goal of theological education. Rowan Williams stated in an interview with Christianity Today (2020:n.p.) that the purpose and nature of theological education is not about a set of issues or problems and, in the broadest possible sense, is learning more about the world that faith creates or the world that faith trains you to inhabit:

$[I] \mathrm{t}$ is about a landscape you move into - the new creation if you like. You inhabit this new set of relationships, this new set of perspectives. You see differently, you sense differently, you relate differently. (n.p.)

You are formed to see, sense and relate in a new way, grounded in the missio Dei.

Determining the purpose or primary goal of theological education will shape the nature and content of the curriculum and will have implications for spiritual formation in the educational structure (Naidoo 2010:189). The DRC formulated a policy document about the formation of missional leaders. Missional leadership is about the transformation of people and institutions and equipping of people and communities to be able to join God's mission to the world (DRC 2013:16). Theological education is key to developing this type of leadership. The policy document makes it clear that the formation of a missional spirituality is thus a crucial part of theological education (DRC 2013:16). The primary goal of theological education can then be described as the formation for missional leaders to equip the church for its missional calling.

Affirming this primary goal is essential for theological education that aspires to be intentional and holistic formation, and consequently spiritual formation. Spiritual formation can and does happen implicitly through current theological education, and spirituality is formed by engaging in all aspects of life, including academics. However, when outcomes are not addressed intentionally, 'we will end up generating other outcomes, some not at all desirable' (Brynjolfson 2010:200).

A theological education curriculum, or any curriculum for that matter, starts with specific outcomes that it wants to achieve to attain its primary goal. These outcomes are usually determined for each module, discipline and degree. However, the theological education outcomes mentioned here will be general, and the overall outcomes focused on a theological, rather than a pragmatic, point of view. Helland and Hjalmarson (2011:loc. 2279) proposed three significant outcomes, or they can be described as areas of equipping, in the formation of missional leaders. To ground this research in practice, the practical suggestions in terms of theological education and pedagogy are applied to theological education in the DRC, and more specifically the theological training at the University of Pretoria's Faculty of Theology and Religion, one of the partner faculties of the DRC. The broad ideas are, 
however, applicable to the broader concept of theological education. These three areas of equipping can be expanded upon towards holistic theological education.

\section{Equip for theological reflection and integration}

The purpose of theology is not only the academic formation of theologians, although this is of great importance, but also equipping leaders for the missio Dei. Helland and Hjalmarson (2011:loc. 2281) stated that the main purpose or telos of theological education should be to equip leaders who will then equip others in what it means to love God from all one's heart, soul, mind and strength, and one's neighbour as oneself. This should be the backdrop for all theology, spirituality and mission. 'It's inadequate merely to offer courses in systematic theology and ethics that are standalone studies abstracted from the practice of theology for spirituality and mission' (Helland \& Hjalmarson 2011:loc. 2282-2283). Theological education should also equip in spiritual directing or guiding beyond pastoral counselling (Helland \& Hjalmarson 2011:loc. 2284). This implies that theological education should cultivate student spirituality. Theology is not only about knowing but also about doing and being. Students and lecturers should develop and practice a 'rule of life' (Helland \& Hjalmarson 2011:loc. 22852287). If spirituality is about life itself, and missional spirituality is about forming and feeding mission, it is clear that theological education for the missional church must attend to the formation of missional spirituality.

\section{Equip for mission and disciple making}

Mission studies only recently became a recognised discipline and mission, and disciple making is not currently the main theme when it comes to any of the disciplines of theology (Helland \& Hjalmarson 2011):

Equipping for a missional spirituality in the academy requires that leaders are taught not only how to exegete Scripture but also how to exegete culture, how to be engaged incarnationally in their communities and how to make disciples. (loc. 2290-2292)

How to be present and participate in God's mission. Williams (2016) linked spirituality and discipleship. Discipleship is a state of being (Williams 2016:1) and an invitation to joyful and flourishing life (Niemandt 2016a:1). Spirituality is staying alive in Christ (Williams 2016:76) and to be human in discipleship and ministry (Williams 2016:78). Niemandt $(2019: 5,9)$ argued that spirituality must align missional leaders in terms of a missional hermeneutic so that spiritual practices can lead to a way of interacting with Scriptures, inspiring the church for its missionary praxis. Missional spirituality is intrinsically part-and-parcel of the process of equipping the church to participate in the missio Dei, to make disciples and to join a journey to a joyful and flourishing life.

\section{Equip for spirituality}

A leader cannot be competent in church ministry without the foundation of spirituality, 'spirituality and virtue are first, then leadership' (Helland \& Hjalmarson 2011:2292-2293). Nelson (2016) wrote about spirituality and leadership and stated that 'leadership is more complex than ever, requiring leading beyond our means' (p. 16). The task of equipping leaders then is not about power and control but about cultivating a missional spirituality. Self-emptied leaders who resist the temptation to be powerful, because as Henri Nouwen stated: 'Power offers an easy substitute for the hard task of love' (Helland \& Hjalmarson 2011:loc. 2295-2296). Theological education cultivates the mind, but it should also cultivate the heart, 'the driving force of our affections, with love as the core desire' (Helland \& Hjalmarson 2011:loc. 2302-2303). This should be reconsidered as the core of the curriculum. 'To participate in mission is to participate in the movement of God's love toward people since God is a fountain of sending love' (Bosch 1991:390).

These three areas of equipping indicate the importance of forming spirituality as fundamental to holistic theological education. The primary goal of theological education, as the formation of missional leaders, is about more than acquiring knowledge about the missional church or even acquiring missional ministry skills, and it is about the formation of a missional spirituality (Brynjolfson 2010):

Surely, the acquisition of more knowledge about God is, by itself, an inadequate outcome for theological education... Knowledge about God should inspire love for God, and love for God, obedience to God. (p. 196)

It should also be noted that spiritual formation is a life-long process and not something that can be seen as accomplished after the completion of formal theological studies. It is thus inherently a goal of theological education to cultivate lifelong learners. Naidoo (2010:187) stated that this formation is a 'lifelong process of becoming, of being formed and developed in the likeness of Christ'.

This primary goal and outcomes of theological education call for theological education to restore the imbalance between spiritual formation, skill development and academic excellence. This restoration is about more than adding 'spiritual qualities' as desired outcomes of theological education. These outcomes are usually present in theological curricula. However, Brynjolfson (2010:198) noted that when theological institutions are to point out where and how these outcomes are generated, vague references are made to times of worship or prayer. This challenge is about more than reorganising theological education by adding new modules or outcomes, and it is not a mere pragmatic approach. This challenge is about deep change and adaptive change and concerns the theological foundations of education. The content of theological education must then be formed by the central theme of mission, the focus of theological education directed to the community and the consequence of theological education in the formation of a missional spirituality. This concludes the second research question about the significance of missional spirituality in theological education. What follows is a proposal for a model of theological education and 
the formation of missional spirituality by engaging reflexively in transforming current practices. This proposal will be made by deliberating a pedagogical model for holistic formation and a syllabus for the formation of missional leaders, answering the third research question, namely, what is a probable model for the formation of a missional spirituality?

\section{A model for holistic theological education}

The pedagogical model and dominant structure of many theological education institutions prioritise academic instruction with some practical exposureand compartmentalise spiritual formation, seen as happening implicitly or informally 'through individual faculty contributions and extracurricular activities' (Naidoo 2010:185-186). Intentional spiritual formation is not typically part of professed formal theological education. Harrison (2017) expressed the importance of holistic theological education by stating:

Formation involves cultivating wisdom as well as providing information, shaping character as well as conveying content and ways of thinking, nurturing holiness as well as equipping with skills. It calls for an educational goal that develops habits, perceptions, a way of being in the world, a kind of theological habitus, combined with a sense of personal wellness and growing spiritual maturity. Christian character and spirituality are integrated with intellectual learning here. (p. 347)

The pedagogical model and structure should take into account that theological education is beyond an academic course, a process of formation. The impression is that current pedagogical models do not promote holistic theological education. The main focus on academic excellence causes an imbalance. As is the case in most of theological education in the orbit of the DRC, and also on many institutions serving mainline churches in the West, the curriculum's structure is focused on books and classroom work, safely removed from real life (Houston 2013:114; Paas 2011:126). The practical exposure is minimal and the intentional formation of spirituality nominal. However, it should be said that effectively integrating the academic, practical and spiritual has rarely been achieved (Kelsey 1992:105).

The challenge of addressing theological education as a process of formation means that resources should be allocated accordingly and all the areas of formation should be deemed essential. A curriculum with an integrated approach aims to generate outcomes in all the areas of formation and learning (Brynjolfson 2010:22). These areas of learning are described by Ellison as knowledge, skills and attitudes. A minimum knowledge base, skills, attitudes and beliefs are the elements for consideration when teaching congregational leaders (Ellison 2009:160). These different areas of learning are also commonly used by others in pedagogical models for theological education: cognitive (knowledge and understanding), skills (abilities) and affective (character formation) (see Brynjolfson 2010:198; Houston 2013:111; Wall
2015:185-186). Learning and formation typically does not take place in these neat categories. And perhaps, it is important that the lines are blurred and the different aspects and areas are seen as more integrated. However, using these aspects and areas of learning of formation is a way to be intentional about holistic theological education. To be able to achieve specific outcomes, there has to be a high degree of intentionality.

A pedagogical model focused on these different aspects of a student's formation and the different areas of learning to cultivate capacities can be regarded as a holistic model - a model that forms a student's head, hands and heart; a model where there is an opportunity for intellectual development, practical exposure and engagement in community and the formation of character; and a model that creates the proper culture for learning and formation and that can lead to the intentional formation of spirituality. It is worth noting again that spirituality and spiritual formation do not denote something abstract or mystic, but a way of life (Naidoo 2010):

When different methods for cultivating spirituality are aligned in an intentional way, the effect will be powerful... Spiritual formation in this case is not simply a goal among others, but a permeation of all educational goals. (p. 193)

The intentional and explicit formation of spirituality then implies attending to the methodology of formation and the context of formation. According to Brynjolfson (2010:199), theological education is inclined to use inappropriate methods; the methods focus on acquiring knowledge and developing critical and analytical skills and thus are not able to intentionally form spirituality. Moreover, intentional spiritual formation requires an appropriate context. Brynjolfson (2010:199) stated that the three areas of education correspond to three contexts:

- Cognitive learning is typically compatible with a formal education context, associated with schools, institutions, classrooms and graded systems of assessment and development.

- Skill development is typically compatible with a nonformal education context, associated with on-the-job learning, systems of certification and the demonstration of competence in specific skills.

- Spiritual formation is typically compatible with an informal education context, associated with learning acquired through our lives in the context outside of an organised or systematised experience.

This poses a challenge. If certain outcomes are to be achieved, there has to be a high degree of intentionality. However, the informal education context, where spiritual formation takes place according to educational theorists, is unstructured and lacks intention, and when education is intentional and structured, it becomes non-formal or formal (Brynjolfson 2010:199). There is a complex relationship between the different learning areas and contexts for learning. Brynjolfson (2010:199) suggested that instead of being intentional about providing learning experiences to 
achieve spiritual formation outcomes, to be intentional about providing the contexts in which certain outcomes can be anticipated. This is a significant insight into intentional spiritual formation. Intentional spiritual formation can take place if theological education can also provide, suggest or anticipate these non-formal or informal contexts. These contexts entail minimum structure and giving up control and imply that lecturers, as well as students, will have to be open to the guidance of the spirit. Intentional spiritual formation can and should thus be part of the theological education curriculum or syllabus.

Albert Einstein's well-known phrase is applicable when it comes to the DRC's theological education: 'Insanity is doing the same thing over and over again and expecting different results'. Missional leaders will not be formed by the same theological education that forms traditional congregational ministers focused on managing, maintenance and ministry to members. Webber (2002:194-195) wrote about a new kind of leadership and stated that this new type of leadership is shaped by: (1) a missiological understanding of the church, (2) theological reflection, (3) spiritual formation and (4) cultural awareness. These four points are also essential when discussing the missional leadership of the DRC and proposing a syllabus for the formation of missional leaders. According to Harrison (2017:347), a syllabus for this type of theological education should include the following core components: minimum knowledge base, pass-on-able habits and skills, and attitudes and beliefs. This has already been established as the different areas of learning and will give shape to the framework. Although these are known as the common learning areas, the balance needs to be restored, and all the areas of learning should be addressed intentionally. The content of theological education must then be formed by the central theme of mission, the focus of theological education directed to the community and the consequence of theological education in the formation of a missional spirituality.

\section{Minimum knowledge base}

Re-framing the cognitive learning area as a 'minimum knowledge base' maintains the significance of theological knowledge and theological reflection. Quality academics are by no means optional or redundant. Yet, this re-framing restores the balance between the different areas of learning. The cognitive learning area is only one part of a student's formation. A minimum knowledge base: (1) is about becoming a life-long learner and (2) emphasises that knowledge is not an end in itself but has to be integrated and reflected on.

Enrolling for formal theological education is thus a start, an introduction, and forms the basis for further learning. 'It is minimum because the model expounded here is one of lifelong learning rather than front-loading education' (Harrison 2017:350). The goal is to form students who learn how to learn. In a report to the Reformed Ecumenical Council (REC
2005), it was also noted that transformational leaders must become life-long learners:

...life-long learners who can 'think on their feet', analyse,
understand and see the interconnections between various
complex systems. They must become flexible and creative. They
must become critical thinkers and reflective practitioners.
Theological education should intentionally equip them with the
necessary skills and attitudes to be such. What is important is not
for students to learn huge amounts of knowledge, but to learn
how to learn: where to get the information they will need, how to
analyse, assess and identify the relevant and important
information, how to comprehend it, how to integrate it into their
practice, apply and use it. (p. 56)

This minimum knowledge base also includes students being equipped for theological reflection and integration. Studying theology is more than acquiring knowledge and applying what was learned. Academic disciplines cannot be abstracted from the practice of theology for spirituality and mission. Williams (2020:n.p.) explains it as follows: 'Don't think the importance of education is what it's going to do for you tomorrow. To me, the question is, what's it doing for you today?' This perspective is one way to integrate the cognitive learning area, most commonly formed in a formal classroom setting, with spirituality and mission. Spirituality and academic theology call for input and critique of the other (Cannell 2006:95). And as seen above, they are irrevocably connected.

Re-framing the cognitive learning area as a 'minimum knowledge base', focusing on students becoming life-long learners and emphasising on theology for mission and spirituality address the first outcome stated as equipping for theological reflection and integration. The cognitive learning area can then be formed by the central theme of mission, but focus on the local community and student's participation in their local communities and intentionally form student's spirituality.

\section{Pass-on-able habits and skills}

Re-framing the skill development learning area as 'pass-onable habits and skills' broadens the focus to include habits, implying a formation of the self rather than mere professional skills and pass-on-able implying the formation of others. Missional ministry is more than acquiring skills or learning about missional practices in a formal context and then applying what was learned in ministry. This learning area especially takes place in a non-formal context. Williams stated (2020:n.p.) that the most effective method for theological education is not to gain the theory and then to go practice it, or to do the practice and then to reflect on it from a distance, 'there's a to and fro all the time'. Banks (1999:126) proposed that theological education orients itself primarily around 'in-service' ministry 'within which intellectual, spiritual, and practical concerns form a seamless whole'. Van Niekerk (2019:246) also suggested that while both mission and spirituality require a process of formation, it is a reciprocal formation between missio- 
formation and spiritual formation. Participating in missional practices thus forms missional ministry and a missional spirituality - being transformed by taking part in transformative practices (Dykstra 1999):

Practices of the Christian faith... are not... activities we do to make something spiritual happen in our lives. Nor are they duties we undertake to be obedient to God. Rather, they are patterns of communal action that create openings in our lives where the grace, mercy, and presence of God may be made known to us. (p. 66)

Helland and Hjalmarson (2011:loc. 906-907) then stated that it is not a matter of just believing our way into spirituality, and we must practice our way. They describe a practice as a task or action that applies a theory or skill in praxis (Helland \& Hjalmarson 2011):

To pray or to read Scripture regularly is a practice. Praxis involves practices, but when you are engaged in the practices, you discover meaning as truth in action. We learn obedience as we practice obedience. We learn humility as we practice humility. We learn truth as we practice Scripture. We learn to love God and neighbour through various practices whose meanings are discovered and revealed in actions. The church embodies its theology through praxis. (loc. 913-916)

Pass-on-able habits and skills refer to these practices. This learning area is about forming (1) habits that are formative and (2) habits that are pass-on-able to form others.

Smith declared that you are what you love and what you desire (see Smith 2016). He denoted that your daily habits and the practices you are immersed in calibrate your love and desire and it becomes second nature. Love is then seen as our most fundamental orientation to the world, 'less a conscious choice and more a baseline inclination, a default orientation that generates the choices we make' (Smith 2016:16). Naidoo (2010:187) stated that authentic Christian spirituality must be integrated into the lives of students, observable wherever they find themselves, in the classroom, church or society. Theological education should be retraining and reforming of our dispositions with intentional habit formation.

Habits should also be pass-on-able. To achieve this, theological education has to be context-driven, 'the focus from the first moment of training being on equipping and enabling the local Christian community in mission' (Harrison 2017:347). Apart from theology and theological education being context-driven, it should also happen in the local context and the local faith community. The local context is the primary locus of education (Harrison 2017:347). Zscheile (2012) stated that from a missional perspective, God and neighbour play central roles in spiritual formation:

Such formation plays out not just within the limited sphere of church gatherings, activities, or programmes... but also in the workplaces, streets, markets, family rooms, and public squares where we encounter our neighbours, especially those who are strangers... Missional theology insists on the importance of the curriculum of the world in spiritual formation, not as a place to be shunned, rejected, or withdrawn from, but rather as a pace to encounter God - especially in those who have been shunned or rejected. (p. 20)

Being missional means to be present in the world in a way that makes disciples and invites people to a flourishing life. Smith (2016:18) noted the importance of imitation information, 'we learn to be virtuous by imitating exemplars of justice, compassion, kindness, and love'. There are various missional practices to engage in to form mission and to form others; however, 'we can't give what we don't have, and what we have to give is who we are' (Helland \& Hjalmarson 2011:225-226). We first must be transformed to be able to transform.

Re-framing the skill development learning area as 'pass-onable habits and skills', focused on formation in and for the local faith community, addresses the second outcome stated as equipping for mission and disciple-making. 'The inculcation of pass-on-able corporate spiritual and missional practices is a promising starting point for training, and indeed for changing the trajectory of theological education to serve a missional ecclesiology' (Harrison 2017:349). The skill development learning area is then formed by the central theme of mission, focused on the local community by engaging in missional practices, acquiring skills through these practices and passing them on, and intentionally form student's spirituality.

\section{Attitudes and beliefs}

The affective learning area, as seen above, poses a challenge. Naidoo (2010:188) noted that educators are not motivated to address intentional spiritual formation as it is 'difficult to quantify and almost impossible to programme effectively'. Brynjolfson (2010:198) also stated that educators resist addressing intentional spiritual formation or affective learning goals because it cannot be objectively measured. It is not merely a matter of lecturers not being motivated or resisting the affective learning areas because it is complicated or hard to measure. The hostility to spiritual formation is entrenched in our culture. We are accustomed to comfort and resist anything that threatens our solace.

The intentional formation of attitudes and beliefs takes place within the informal learning context. Moreover, as determined above, it is not possible to provide intentional learning experiences to achieve certain spiritual formation outcomes, but it is possible to be intentional about the context where certain outcomes can be anticipated. Brynjolfson (2010) stated that the most effective ways of forming attitudes are through instrumental learning and observational learning:

Instrumental (or operant) learning is the result of an individual learning on their own through exposure to experiences within a given context, it produces attitude transformation out of life's experiences. Observational learning is strongly relational. Participants observe a model (a professor, a missionary in 
residence, an international student, a pastor, etc.) and assimilate desirable qualities. (p. 199)

This learning area is thus about being intentional about context and creating (1) the space, opening or opportunity for formation to take place and (2) relationships within this context.

Creating this space, opening or opportunity does not imply a strict arrangement, but for it to be intentional, it has to involve a dedicated time, place and guidelines. This time, place and guidelines will be referred to as a spiritual formation programme for lack of a better word and to emphasise the intentionality. In this space, the main guideline is an openness towards the spirit for guidance. Being vulnerable, letting go of the need to be in control and giving power over to God. This context thus relies on relationships, with God and others. According to Brynjolfson (2010:200), this context will be highly relational, requiring programmes outside the learning experiences of classroom or ministry practice, which intentionally cultivate spirituality; he suggests, for example, mentoring programmes, adviser groups or peer facilitation groups. Even though spiritual growth is not easily measured, 'we know it occurs in the context of authentic community' (Brynjolfson 2010:200). Amalraj (2009:9) affirmed that authentic spirituality is discovered in relationships, built on the foundation of a relationship with God. Harrison (2017:351) stated that the aim is a journey that profoundly shapes attitudes and beliefs, 'through action-reflection in context; and a journey that will not just be shaping the trainee but other trainees, the Christian community and, hopefully, others within the wider community'.

While acknowledging the challenges of the affective learning area, the significance of the intentional formation of attitudes and beliefs is also evident. The affected learning area can be addressed by creating a space, opening or opportunity, for vulnerability and reflection, in relationships with others and deeply aware of God's presence - a spiritual formation programme. This also addresses the third outcome stated as equipping for spirituality. The affective learning area is then formed by the central theme of God's mission, focused on the presence of others, and intentionally forming spirituality.

This description of a modal for holistic theological education, a pedagogy that is intentional about spiritual formation and a syllabus focused on a minimum knowledge base, pass-onable habits and skills and attitudes and beliefs, answers the third research question. Holistic theological education implies being intentional about the formation of a missional spirituality.

\section{Missional metanoia}

Missional transformation requires missional leadership being equipped and equipping others for God's mission. Theological education to this end is about more than acquiring a new skill set or completing an extra academic module on methods for becoming a missional church. Missional leadership requires the transformation of the self - a missional metanoia. This requires a holistic theological education that forms a missional spirituality. A transformation of the self is to be able to transform. Wright (2008:270) challenged the church - if the gospel is not transforming you, will it transform anything else? Helland and Hjalmarson (2011:loc. 107-216) stated that we can bring transformation only to the extent to which we are transformed, a missional spirituality is thus imperative for transformation. 'Transformation is only possible if it is nourished by spirituality. If mission is all about a "transformative spirituality", then the church needs a missional spirituality' (Niemandt 2016b:89). 'A key insight of the initial missional church conversation is that it was not primarily about the church developing yet another strategic approach for reaching a new generation' (Van Gelder \& Zscheile 2011:7). The emphasis should be on formation for God's mission - on being God's people and then doing by participating in God's mission. Cultivating a faithful missional community is thus an ongoing process of formation and reformation (ed. Guder 1998:180). Cultivating students to be missional leaders is also an ongoing process of formation and reformation. It is not adopting a framework document or an adjusted curriculum, more leadership development programmes or research on being a missional church, which is needed to become a missional church, it is a missional spirituality and ultimately a missional metanoia. 'A missional spirituality is a spirituality that forms and feeds mission' (Helland \& Hjalmarson 2011:loc. 239-240). Thus, the formation of a missional spirituality is fundamental to theological education.

\section{Acknowledgements \\ Competing interests}

The authors declare that they have no financial or personal relationships that may have inappropriately influenced them in writing this article.

\section{Authors' contributions}

D.N. was responsible for conceptualisation, fieldwork and literature research, write-up of the draft and application of methodology. N.C.N. was responsible for conceptualisation, directing methodology, project administration, supervision, review and editing of the draft.

\section{Ethical considerations}

This article followed all ethical standards for research without direct contact with human or animal subjects.

\section{Funding information}

This research received no specific grant from any funding agency in the public, commercial and not-for-profit sectors.

\section{Data availability}

Data sharing is not applicable to this article as no new data were created or analysed in this study. 


\section{Disclaimer}

The views and opinions expressed in this article are those of the authors and do not necessarily reflect the official policy of position of any affiliated agency of the authors.

\section{References}

Amalraj, K.J., 2009, 'What shapes our spirituality in missions?', The Journal of the WEA Mission Commission 8(1), 9-11.

Banks, R., 1999, Reenvisioning theological education: Exploring a missional alternative to current models, William B Eerdmans, Grand Rapids, MI.

Bosch, D.J., 1991, Transforming mission: Paradigm shifts in theology of mission, Orbis, Maryknoll, New York, NY.

Brynjolfson, R.W., 2010, 'Missionary training and spirituality: Spiritual formation in theological education', in D. Werner, D. Esterline, N Kang \& J. Raja (eds.), Handbook of theological education in World Christianity: Theological Handbook of theological education in World Christianity: Theological
perspectives-Ecumenical trends - Regional surveys, pp. 196-202, Regnum Books perspectives - Ecumen
International, Oxford.

Cannell, L., 2006, Theological education matters: Leadership education for the church, EDCOT Press, Newburgh, IN.

Dutch Reformed Church (DRC), 2013, Framework document on the missional nature and calling of the DRC, viewed 02 September 2020, from https://www.academia. edu/9789282.

Dykstra, C.R., 1999, Growing in the life of faith: Education and Christian practices, Geneva Press, Louisville, KY

Ellison, P.T., 2009, 'Doing faith-based conversations. Metaphors for congregations and their leaders', in P. Keifert (ed.), Testing the spirits: How theology informs the study of congregations, pp. 159-179, William B Eerdmans, Grand Rapids, MI.

Endean, P., 2005, 'Spirituality and theology', in P. Sheldrake (ed.), New SCM dictionary of Christian spirituality, pp. 74-79, SCM Press, London.

Guder, D.L. (ed.), 1998, Missional church: A vision for the sending of the church in North America, William B Eerdmans, Grand Rapids, Ml.

Harrison, M., 2017, 'Missional leadership and theological education', in C. Burger, F. Marais \& D. Mouton (eds.), Cultivating missional change: The future of missional churches and missional theology, pp. 338-353, Bible Media, Wellington.

Helland, R. \& Hjalmarson, L., 2011, Missional spirituality. Embodying God's love from the inside out, InterVarsity Press, Downers Grove, IL.

Hernandez, W., 2006, Henri Nouwen: A spirituality of imperfection, Paulist Press, New York, NY.

Houston, B., 2013, 'The future is not what it used to be: changes and choices facing theological education in Africa', in I.A. Phiri \& D. Werner (eds.), Handbook of theological education in Africa, pp. 108-116, Regnum Books International, Dorpspruit.

Johnson, B.C. \& Dreitcer, A., 2001, Beyond the ordinary: Spirituality for church leaders, William B Eerdmans, Grand Rapids, MI.

Kelsey, D.H., 1992, To understand God truly. What's theological about a theological school, Westminster John Knox Press, Louisville, KY.
Kourie, C., 2009, 'Spirituality and the university', Verbum et Ecclesia 30(1), 148-172. https://doi.org/10.4102/ve.v30i1.67

Naidoo, M., 2010, 'Spiritual formation in protestant theological institutions', in D. Werner, D. Esterline, N. Kang \& J. Raja (eds.), Handbook of theological education in world Christianity: Theological perspectives - Ecumenical trends - Regional surveys, pp. 196-202, Regnum Books International, Oxford.

Nelson, A.E., 2016, Spirituality and leadership, Summit Crest Publishing, Pretoria.

Niemandt, C.J.P., 2016a, 'Rediscovering joy in costly and radical discipleship in mission', HTS Teologiese Studies/Theological Studies 72(4), a3831. https://doi. org/10.4102/hts.v72i4.3831

Niemandt, C.J.P., 2016b, 'Transformative spirituality and missional leadership', Mission Studies 33(1), 89. https://doi.org/10.1163/15733831-12341435

Niemandt, C.J.P., 2019, 'A missional hermeneutic for the transformation of theological education in Africa', HTS Teologiese Studies/Theological Studies 75(4), a5406. https://doi.org/10.4102/hts.v75i4.5406

Paas, S., 2011, 'Prepared for a missionary ministry in 21st century Europe', European Journal of Theology 2, 119-130.

Reformed Ecumenical Council (REC), 2005, Clerical and lay leadership, Report to the REC Netherlands, Assembly 2005, Utrecht.

Schneiders, S., 1986, 'Theology and spirituality: Strangers, rivals or partners?', Horizons 13(2), 253-274. https://doi.org/10.1017/\$036096690003632X

Schneiders, S.M., 2002, 'Biblical spirituality', Interpretation 56(2), 133-142. https:// doi.org/10.1177/002096430005600202

Sheldrake, P.F., 2010, Explorations in spirituality: History, theology, and social practice, Paulist Press, New York, NY.

Smith, J.K.A., 2016, You are what you love: The spiritual power of habit, Brazos, Grand Rapids, MI.

Van Gelder, C. \& Zscheile, D.J., 2011, The missional church in perspective. Mapping trends and shaping the conversation, Baker Academic, Grand Rapids, MI.

Van Niekerk, P.I., 2019, 'Missional spirituality and the embodiment of imperfection', unpublished $\mathrm{PhD}$ thesis, University of Pretoria.

Volf, M. \& Croasmun, M., 2019, For the life of the world. Theology that makes a difference, Brazos, Grand Rapids, Ml.

Waaijman, K., 2006, 'What is spirituality?', Acta Theologica Supplementum 8, 1-18.

Wall, R.M., 2015, 'A transforming model of mission training: A case study from All Nation Christian College, UK', in S. Bevans, T. Chai, N. Jennings, K. Jørgensen \& D. Werner (eds.), Reflecting on and equipping for Christian mission, pp. 181-193, Regnum Books International, Oxford.

Webber, R.E., 2002, The younger evangelicals: Facing the challenges of the new world, Baker Books, Grand Rapids, MI.

Williams, R., 1990, The wound of knowledge. Christian spirituality from the New Testament to St. John of the Cross, Cowley Publications, Cambridge, MA.

Williams, R., 2016, Being disciples, SPCK, London.

Williams, R., 2020, Rowan Williams: Theological education is for everyone. To do theology is to rediscover the strangeness of the Christian framework, viewed 21 August 2020, from https://www.christianitytoday.com/ct/2020/august-webonly/rowan-williams-theological-education-for-everyone.html.

Wright, N.T., 2008, Surprised by hope, HarperOne, New York, NY.

Zscheile, D.J., 2012, 'A missional theology of spiritual formation', in D.J. Zscheile (ed.), Cultivating sent communities, pp. 1-28, William B Eerdmans, Grand Rapids, MI. 